\title{
The Contribution of Forensic Science to Establishing the Truth in Criminal Proceedings
}

\author{
By Elena-Ana Iancu*
}

\begin{abstract}
This article is intended to highlight, on the one hand, the role played by forensic science (forensics) among criminal sciences in Romania, and, on the other hand, to present the specifics of forensic science in order to delineate it from other related sciences. Through an interdisciplinary approach, taking into account the fact that forensic technique, forensic tactics and, last but not least, forensic methodology serve the finding of truth in a criminal case, as well as the prevention and/or combating of deeds provided by criminal law, we will emphasise its autonomous nature in relation to other sciences, although the aims of sciences in the field of criminal sciences are common. The delineation of forensic activities from activities specific to other disciplines is essential for the substantiation of criminal policies, for drafting amendments of criminal legislation, putting forward proposals for best interinstitutional/intrainstitutional practices, especially when investigation is carried out by joint teams, and sometimes for transnational crimes.
\end{abstract}

Keywords: Forensic science; Expert; Specificity; Methods of Proof.

\section{Introduction}

In order to highlight the role of forensic science among criminal sciences, we consider it necessary to refer to the way in which forensics is defined as a science, the type of institutions whose curricula include forensics, the university degree programmes whose curricula include the study of this discipline, the general regulations containing provisions that have an impact on investigation activities, as well as the special laws governing the activities of the forensic experts.

Given the tripartite structure of forensic science as a science in Romania, taking into account its specificity, in view of the connection of forensics with other criminal sciences, through the method of scientific documentation, we may delineate the concepts used in forensics so as to highlight the specific features of activities included in forensic technique, forensic tactics or forensic methodology, which are sometimes closely related to the terminology used in the evidentiary processes regulated in the Criminal Procedure Code of Romania.

We also took into consideration, in the context of this article on forensic science, the need to contribute to sustainable development in the field of law. Each specialist who carries out activities specific to crime investigation and is a participant in the criminal proceedings also promotes the goals proposed by the 2030 Agenda for Sustainable Development - document adopted in 2015 at the

*PhD Habil., Professor, Doctoral School of Law, "Alexandru Ioan Cuza" Police Academy, Bucharest, Romania; Dean, Faculty of Juridical and Administration Sciences, Agora University of Oradea, Romania. E-mail: anaelena2009@yahoo.com. 
UN General Assembly in New York, comprising 17 goals, as well as the values of sustainable development at national and European levels, as reflected by the National Strategy for Romania's Sustainable Development 2030, drafted by the Department for Sustainable Development ${ }^{1}$. In this respect, we refer to Goal 4 "Quality Education" and Goal 16 - "Peace, Justice and Effective Institutions". As a result, all participants involved in the criminal proceedings, regardless of their situational plan, having the rights and fulfilling the obligations associated with their legal standing, must reflect upon their own actions or inactions, taking into account the provisions of the laws in force and the current and future impact of their actions, including as part of the process of sustainable development of institutions, by promoting interpersonal (group, public, mass) relationships regardless of the form of communication chosen or required by law.

Thus, in the case of participants, both intrapersonal communication and the method of interpersonal communication chosen, in all their forms, contribute to the development of institutions, the creation of a functional judicial system and of increased social capital.

Remembering the axioms of communication and the methods of communication that may be used in order to establish the truth in a criminal case, we find that written documents, verbal messages and non-verbal decoding are essential in the criminal investigation process, having the potential to validate or invalidate the means of evidence, the carrying out of the hearing of persons in compliance with tactical rules (e.g. without suggestive questions or reactions of approval/ disapproval upon receiving answers which might also be influenced through nonverbal communication), the corroboration of the evidence, and the observance of the deadlines stipulated by the criminal law, including those regarding the performance of judicial forensic expertise.

Being aware of the developments of forensics as a science in relation to the legislative changes that have occurred over the last 10 years in Romania, we will emphasise, through the historical method, on the one hand, the scientific foundations of identification - from classical to modern ones - and, on the other hand, we will highlight the succession of regulations which have had an impact on evidentiary processes. As a result, we will refer to modern systems used in forensic investigation, taking into account the trace-formation process, the modern means of searching for and detecting traces, the limits of tracepreservation in the context of the regularity of the transformation process, the possibilities of exploiting traces within the limits of the existing technique.

The interdisciplinary and/or multidisciplinary approach is suitable for delineating forensics from other related sciences without which it would not be able to achieve its purpose, such as criminal law, criminal procedure law, and criminology.

\footnotetext{
${ }^{1}$ According to Romanian Government Decision no. 313/2017.
} 


\section{Principles that Emphasise the Specificity of Forensic Science}

In the Romanian literature specialised in forensic science ${ }^{2}$, there are numerous definitions given to forensic science which refer to the tactical methods and the technical means applied in the search for and detection of traces, the investigation of the crime scene in the case of committing acts provided for by criminal law, as well as in the prevention of crimes.

In Romania, the forensic science discipline is studied within faculties that have the law degree programme included in their educational offer and within the educational institutions of the Ministry of Internal Affairs, a different number of hours being allocated thereto, according to the specifics of the educational institution. The initial training and professional development of forensic workers is a constant concern of education providers, who initiate and develop undergraduate, master's or doctoral degree programmes having in their curriculum the forensic science discipline or disciplines that contribute, through the content of the discipline sheets, to the development of skills specific to crime investigation specialists, having sound knowledge of the causes that determine the evolution of criminal phenomena and of the factors contributing to their dynamics. Thus, there are universities which, in addition to the educational offer of law faculties, through other faculties that have related multidisciplinary programs, through the curricula of the second cycle of studies - Master's degree (e.g., a Master's degree program of Forensic Chemistry, a Master's degree program of Applied Forensic Studies), aiming at the sustainable development of human resources that carry out activities in related fields which contribute to establishing the truth in criminal proceedings, offer Master's degree students the opportunity to study the discipline of forensic science. Also, disciplines such as forensic technique, forensic tactics and/or crime investigation methodology, may be studied through postgraduate programs of continuous professional training and postgraduate professional improvement programs provided by educational institutions.

According to the principle of legality, the activities carried out by forensic experts involved in criminal investigations may only be ordered, performed and exploited in compliance with the provisions of the Criminal Procedure Code. However, the tactical methods applied and the technical-scientific means used during their deployment must also be based on the rules of forensic science set out in best practice guides, which are not detailed in the legislation but are applicable in the matter.

According to the principle of the regularity of trace creation and preservation, the forensic value of the changes occurring during the perpetration of the acts provided by criminal law depends on the manner in which the changes were formed initially, on their category, on a number of environmental factors, internal and external, contributing both to the formation of traces and to their preservation, as well as on the methods and procedures applied during the search for, discovery, highlighting, recording and collection of the traces.

\footnotetext{
${ }^{2}$ Mircea (2004) at 3 and Stancu (2007) at 12.
} 
From the principle of identity, it results that an object is identical only to itself, at a given point in time. Identity is of a relative nature ${ }^{3}$. However, in the process of forensic identification, on the one hand, as a result of the fact that both the trace-forming object and the trace-receiving object may undergo changes, and on the other hand, given that the conservation of traces is dependent on the environmental factors that act upon them, identity is the result obtained by going through the identification process ${ }^{4}$. In the Romanian Criminal Procedure Code, in Title IV which is entitled "Evidence, Methods of Proof and Evidentiary Processes", the legislator reserved Chapter III to the "Identification of Persons and Objects". Thus, Articles 132-137 contain general provisions applicable to the identification of persons and objects, without showing the rules according to which this activity is carried out. In this respect, we highlight Article 132, bearing the generic title "Purpose and Scope of this Measure", which provides that such a measure may be ordered if the identification of persons or objects is necessary in order to achieve the purpose, which is to clarify the circumstances of the case. It is apparent from the chapter that the legislator refers only to the identification made by persons, who have to be heard with regard to the person or object they are supposed to identify, before the identification is made. Also Article 136 bearing the generic title "Other Identifications", complements the meaning of the chapter as a general statement, the application of Article 134 "Identification of Persons" being, however, limited - "Identification of voices, sounds or other sensory perception elements". In forensic literature, this measure is detailed as "presentation for recognition", including the tactical rules applicable to this activity.

While the principle of finding out the truth is specific to disciplines in the criminal sciences branch, forensic science, through the tactical methods and the technical means it uses, contributes to the investigation of the crime scene, to the conduct of evidentiary processes, to the synthesis, analysis and comparison of the acts actually committed, and helps to associate the constitutive elements of the offence committed so that the correct legal classification may be performed, and the most appropriate evidentiary processes needed in order to investigate the offence may be ordered, as part of the criminal investigation or criminal prosecution.

\section{Specifics of Forensic Activities and Evidentiary Processes}

Expert reports and fact finding are regulated in Chapter IV of the Criminal Procedure Code of Romania titled "Evidence, Methods of Proof and Evidentiary Processes", and chapter VII titled "Expert Reports and Fact Finding" whose title was amended in $2013^{5}$.

\footnotetext{
${ }^{3}$ Ionescu (2008) at 19-20.

${ }^{4}$ Mircea (2004) at 12.

${ }^{5}$ Through Article 102, point 115 of Law no. 255/2013 implementing Law no. 135/2010 on the Criminal Procedure Code and amending and supplementing some regulatory acts containing criminal procedural provisions, published in the Official Journal no. 515 of 14 August 2013.
} 
Thus, Art.172-Art.183 contain provisions regarding the ordering of an expert report, the appointment of the expert, the rights and obligations of the expert, the cases of incompatibility, the replacement of the expert, as well as the procedure for conducting an expert report. There are also provisions regarding the parties that should have the expert report conducted and cases where it is possible to order a supplementary expert examination or a new expert examination. Since 2014, when the Criminal Procedure Code came into force, the expert's hearing is mandatory in cases where the expert report is not complete, where there are contradictions between the conclusions of the expert report and the content of the report, where the conclusions are contradictory or ambiguous. Although in the general part of the criminal procedure reference is made to the evidentiary process, the expert report or the fact-finding report may be carried out by using technical means that are specific to the type of expert examination or fact finding, by experts in the field of expertise, and by way of exception by a specialist working within judicial bodies or by an external one ${ }^{6}$ in situations where there is a danger of "disappearance of evidence or of change of a factual situation, or where the urgent clarification of facts or circumstances of the case is necessary" ${ }^{\prime 7}$. The limits for obtaining these methods of proof may be stated and put in relation to the quality of the technology used, the training of the workers involved in the process of exploiting the trace being examined, the method used in their performance. Even when referring to modern methods and means of identification, knowing the scientific foundations of identification, understanding the identifying characteristics and the classical, relatively stable elements of the trace-forming or receiving objects are elements that are essential to drawing the conclusions, and all the more so to explaining the way in which they were reached, in the case of an expert's hearing.

In the matter of the evidentiary processes of hearing of persons, the general rules are laid down in the Criminal Procedure Code, Chapter II, Section 1, Articles 104-106. The following sections of the chapter contain provisions covering the hearing of the suspect or defendant (Article 107-110), of victims (aggrieved parties), as the case may be, of civil parties and of parties with civil liability (Art. 11-Art. 113). An important part is given to the hearing of witnesses (Art. 114-124) and to witness protection (Art. 125-Art. 130).

In order to avoid mental manipulation and to validate or invalidate statements without influencing one's intimate conviction, the observation, decoding and interpretation of non-verbal communication may constitute an advantage for members of the crime scene investigation teams, in cases where people are present near the perimeter of the crime scene, as well as in view of discovering negativecontroversial circumstances at the crime scene.

The possibility of ordering the hearing of the forensic expert in the criminal trial may lead to situations in which the results of the process of identification as recorded by the conclusions of the expert report are explained and detailed during the trial. This aspect is reflected by Article 179 of the Criminal Procedure Code, which bears the generic title "Hearing of Experts", which in paragraph 1 states that

\footnotetext{
${ }^{6}$ Article 172 of the Criminal Procedure Code, paragraph 10.

${ }^{7}$ Article 172 of the Criminal Procedure Code, paragraph 9,
} 
"during the criminal investigation or the trial, an expert may be heard by the criminal investigation body or by the court" if the judicial body believes that "such hearing is necessary to clarify the expert's findings or conclusions". The same Article, in paragraph 3, provides that an expert's hearing is conducted according to the provisions regarding the hearing of witnesses, Articles 114-130.

In the Criminal Code of Romania, the Special Part, in Title IV, bearing the generic title "Crimes of Obstruction of Justice" ${ }^{8}$ Article 273, under the generic title "False Testimony", in paragraph 2, the aggravated form of the criminal offence at letter c, provides that the active subject of the offence may be "a person who prepares an expert report or an interpreter". As a result, the expert may be the subject of the criminal offence of false testimony if "in a criminal, civil or other proceeding in which witnesses are heard, gives false statements, or does not tell everything they know regarding the essential acts or circumstances in relation to which they are heard" ". If the witness is an active subject of the abovementioned offence in its simple form (the legal punishment is imprisonment for no less than 6 months and no more than 3 years or the payment of a fine), we notice that the expert will be held responsible for the aggravated form of the offence, as a circumstantial active subject, the punishment provided by the law being imprisonment for no less than 1 and no more than 5 years, without alternative fine.

Although, currently, forensic science workers have information technology at hand, and implicitly, a modern means - the computer, which is integrated in an international/national or local automated system that helps the specialist to gather traces/impressions, to process them, as well as in the process of recognition, verification, identification and storage thereof, the automated programs with work modules which are used in order to carry out the evidence-gathering procedure as part of forensic expertise are based on the classic methods of comparison by juxtaposition, overlapping (through transparency, differences in shades of colour, alternative lines, bicolour), linear continuity (horizontal or vertical).

The use of information technology, of modern means of forensic identification through the complex software they involve might leave the impression that experts/specialists should only have knowledge of the work module which is used in the performance of the expertise/technical-scientific finding report in a certain field, without requiring a thorough knowledge of the notions of forensics in general and of the technique used in classical forensics in particular.

Of course, this is not true. There are numerous forensic activities which are interdependent, this aspect being true both for fieldwork and for activities carried out in specially designed premises or laboratories, each of them having to observe specific tactical rules and methods and means which are recommended in order for the activity to achieve its goal or for the traces to be exploited in the best possible way in an identification process. But, regardless of the technical means used, the achievement of the purpose of an identification process depends on several factors, such as: human factors, equipment used in the identification process, factors related to the complexity of the program, as well as factors depending on the

\footnotetext{
${ }^{8}$ Articles 266-288.

${ }^{9}$ Article 273, paragraph 1 , the simple form of the offence, according to its typical nature.
} 
limitations of the technology used, or/and wear and tear factors. In this respect, we provide the following examples:

- The different forensic value of the impressions/traces used, which is obviously determined by the quality of the search, discovery, highlighting, recording (fixation), collection, and transportation/ preservation activities;

- The benefits provided by the technical-scientific means, both in terms of the takeover of the images as permitted by the system (scanner, analogue video camera, analogue videotape recorders, digital photo cameras, any digital information storage media, peripherals of certain systems that allow direct fingerprinting), as well as the worker's level of knowledge and training at each stage of the activity, so as to maximise the benefits of the system in a certain process of forensic identification, on the basis of a trace, impression or image;

- The state of operation of the peripheral equipment necessary for the proper operation of the means in question, as a system (generally, a scanner, a colour printer, a PC, a video printer), for example in the case of Lucia Forensic, the calibration of the scanner prior to taking the image is essential;

- The observance of the main steps in the program being used and the filling-in of the mandatory fields in order to enable the opening of the application and comparison in the identification process;

- Establishing and marking general and individual features, calibrating an image and determining the dimensions of the objects or the routes illustrated thereby, bringing two images to the same scale, position and orientation for comparison purposes, comparing two static images or a static image and a live one, printing, saving and managing all the results of processing may influence the achievement of the purpose of the identification process, namely the establishment of identity.

\section{The Activity of Forensic Expertise in Romania}

The general legal framework for the activity of expertise is provided by Ordinance no. 75 of 24 August 2000 on the organisation of forensic expertise. In Romania there are two national forensic science institutes, in two ministries: the National Institute of Forensics within the Ministry of Internal Affairs and the National Institute of Forensic Expertise within the Ministry of Justice. At territorial level there are forensic services in each County Police Inspectorate that has as subordinate structures Forensic Science Services, and therefore, forensic experts. Judicial forensic expertise may also be prepared by authorised experts working in accredited private laboratories who are listed in the Nominal Table of authorised forensic experts "established at national level, drawn up according to specialties and updated by the Ministry of Justice"10. Depending on the expertise specialties, various categories of traces or impressions may be

\footnotetext{
${ }^{10}$ Article 1, paragraph 3 of Ordinance 75/2000.
} 
arranged and exploited. The same Ordinance, in Article $2^{11}$ provides for the following forensic expertise specialties:

a. Graphical and technical expertise of documents;

b. Print-related expertise of foot and hand traces;

c. Expertise of traces left by beings and objects;

d. Ballistic expertise of arms and munitions;

e. Physical and chemical expertise of material evidence;

f. Forensic expertise in land traffic accidents;

g. Forensic expertise in aviation traffic accidents;

h. Forensic expertise in maritime and fluvial traffic accidents;

i. Forensic expertise in explosions and arson;

j. Voice and speaking expertise;

k. Images expertise;

1. Biological expertise;

m. Genetic expertise;

n. Digital data and application expertise;

o. Simulated behaviour detection expertise (polygraph);

p. Drugs and psychotropic substances expertise."

However, regardless of the specialty, the expertise may be carried out by official experts and/or authorised independent experts, according to the provisions of the Procedure Code ${ }^{12}$.

As a rule, the criminal investigation body, through a prosecutorial order, or the court, through a resolution ${ }^{13}$, appoints a single expert. If the court orders an evidence-gathering procedure, the prosecutor may request that an expert recommended by him/her should participate in the expertise. The same possibility is given to the parties ${ }^{14}$ and the main procedural subjects ${ }^{15}$ regardless of who ordered the procedure.

The evolution of the legislation, the expansion of information technology, the diversification of the means of recording of the crime scene, including through the evolution of the judicial forensic (investigative) photography performed by unmanned aerial vehicles ${ }^{16}$ brought about novelties in judicial forensic expertise, by broadening the possibilities to illustrate through photos the demonstration contained in the expertise. In the same sense, criminal investigation bodies have new opportunities to document the case by recording the crime scene, recording the changes that resulted from illegal activities, as well as illustrating the results obtained or drawing up the photo composition. We provide, as an example, the platform used in the field of forensic science "Lucia Forensic" with work modules, which is used in order to capture traces/ impressions, as well as for processing,

\footnotetext{
${ }^{11}$ Amended by Law 156/2011, published in the Official Journal no. 519 of July 22, 2011.

${ }^{12}$ Article 172, paragraph 4.

${ }^{13}$ Article 173, paragraph 1, in relation to paragraph 2 of the Criminal Procedure Code.

${ }^{14}$ The defendant, the civil party, the party with civil liability, as indicated by Article 32 of the Criminal Procedure Code.

${ }^{15}$ The suspect and the victim, as indicated by Article 33 of the Criminal Procedure Code.

${ }^{16}$ Iancu \& Păcurariu (2018) at 33-39.
} 
comparing, storing and archiving them, offering various advantages and opportunities in the preparation of specific expertise: fingerprint-related (dactyloscopic) expertise, expertise of traces left by evidence (traceological expertise), graphical expertise, ballistic expertise, based on the means of recording (fixation) used during the course of judicial activities on the field. Also, the Lucia Forensic software may be used to determine the dimensions of the corpus delicti objects, the distances required in the stage of demonstration by comparison, the angles which are essential to identifying forgeries, wear details, or identification characteristics reflected in the negative in the trace discovered, in the process of their exploitation in the laboratory. With regard to the identification of persons by their external features, we highlight the spoken portrait and the identikit, which may be achieved either by using the specific software or by having a forensic artist draw the identikit/ sketch portrait (forensic art), which artist should be endowed with talent, artistic skills and solid knowledge of judicial psychology, anatomy and anthropology. This is why, in forensic science, too, non-verbal communication is important in establishing a relationship of trust between investigators, artist, and the interrogated person. On the one hand, a truthful witness who is available for providing information and has no interest in the criminal case, can contribute to successfully generating the portrait of the wanted person, and on the other hand, the feedback from law enforcement specialists will negatively or positively influence the forensic artist and will highlight the effectiveness of the technical method in the process of investigation of a crime.

\section{Findings/Results}

Through its specific features, forensic science makes an important contribution to the prevention, discovery and investigation of offences, on the basis of the discovery of changes made in the environment, correlating the data stored and the computer systems managed by Forensic Science Services of the County Police Inspectorates or of the regional or national Forensic Institutes. Through the knowledge, use and selection of the most appropriate interinstitutional and/or intra-institutional forms of communication (written, verbal, non-verbal), in accordance with the legislation in force, by making use of the information obtained by reference to the situational plan specific to relations in the judicial activity, forensic specialists and/and forensic experts are involved in the criminal proceedings, along with other criminal trial litigants.

If we refer to the investigation of the crime scene and we take into account the specific activities that forensic experts may carry out within the investigated perimeter (searching for the traces, recording the crime scene by making the specific measurements in order to determine the ratio of the traces, by recording the crime scene by means of the investigative photography, by analysing the behaviour of the photographed subjects resulting therefrom, in cases where, after the acts provided by the criminal law were notified, the investigators came into contact with the perpetrator or the participants in the criminal act (co-perpetrator, instigator, accomplice) during the investigation of the crime scene. Such a 
circumstance could be exploited by the participants, either in order to transmit various messages to one another through the media directly in the information society, or to decode the non-verbal communication of investigators/members of investigation teams, anticipating their reaction and/or positioning in relation to the clues and/or first statements obtained. As a result, the application of valid rules in any investigation of the crime scene and the readiness to observe and decode the communication of the people around may be essential in the process of developing the versions in question and in corroborating the clues discovered since the phase of static investigation of the crime scene. Compliance with rules such as: the conduct of the investigation at the crime scene as soon as possible, in a thorough, planned manner, by observing moral requirements, under a single leadership, highlights the peculiarities of the evidence-gathering procedure, with reference to the fact that the investigation team may include forensic experts, forensic laboratory specialists of the county police inspectorates, depending on the type of offence committed and taking into account their work-related duties.

Also, before the punishment in the case is individualised, the participants in the criminal trial interact with one another, at some point, including in the trial stage, when the hearing of the expert, of the interpreter may be ordered or the judicial investigation may be ordered, and thus the forensic specialists or experts may participate in the determination of the actual circumstances in which the act was committed. In this respect, some relevant aspects may be the following: determining the manner in which a crime has been committed; identifying the means used in the illegal activities; assessing the state of danger created for the protected value; determining the nature and seriousness of the result produced or of other consequences of the offence; identifying the reason for the perpetration of the offence, the purpose pursued by the perpetrator; establishing the perpetrator's conduct before, during and after committing the offence, as well as during the criminal proceedings.

Although, as a result of the amendments to the Criminal Procedure Code ${ }^{17}$, the rule in the matter is expertise, not fact-finding, "when there is a danger related to the disappearance of evidence or to the change of a factual situation, or when the urgent clarification of facts or circumstances of the case is necessary", the conducting of a fact-finding may be ordered. This may mean that forensic specialists are present at the crime scene in order to draw up the fact-finding report, in addition to other activities specific to crime scene investigation, in the static and/or dynamic phase/s. In such cases, if the judicial bodies believe that "an expert opinion is necessary or when the conclusions of the fact-finding report are challenged", the development of an expert report may be ordered, according to the provisions of Article 172, par. 12 of the Criminal Procedure Code. We note that, on the one hand, the specialist present at the crime scene for the purpose of conducting the fact-finding can only be heard as a witness in court, not as a circumstantial subject. As a result, there will the simple form of the offence of false testimony, while the expert will be held responsible for the aggravated form

\footnotetext{
${ }^{17}$ Which were substantial in 2014.
} 
of the offence. On the other hand, protection measures may be ordered in relation to the expert under the same conditions as those regarding the witness ${ }^{18}$.

Throughout the evidentiary processes, especially during the hearing of persons, in the case of interviews required in order to draw the identikit, by asking for impressions directly, it is important for the forensic expert/artist to know that any act of communication falls within a situational logic, that the person being heard communicates differently depending on the position he/she has in relation to at least the following aspects: his/her legal standing (locus standi), the spiritual content of the communication, what is the intention of his/her statements, what is the real purpose of the simulation, etc.

While in the investigation of the crime evidence-gathering procedures will be ordered for which specific preparation measures are required, the tactical rules and the means necessary in order to carry out the activity as such are to be found in internal regulations and best practice guides. Some of these rules and means are: the search, the re-enactment, the (voluntary or forced) seizure of objects, the taking of photos, and the (voluntary or forced) seizure of documentary evidence. The knowledge of the photographic technique, the knowledge of the typology of the person being searched and the putting to use of elementary judicial psychology knowledge, the tactical rules applicable to the types of search (house, computer, body, vehicle search) are stated in the specialised doctrine relating to the field of forensic science and in internal regulations, whereas the substantive and formal issues regarding the acts through which those activities are ordered, the judicial procedure that must be followed in order for them to be carried out legally are stipulated in the Criminal Procedure Code.

\section{Conclusions}

The delineation of forensic activities from activities specific to other disciplines is essential for the development of criminal policies, the substantiation of changes in criminal legislation, for proposals of best interinstitutional/ intrainstitutional practices, especially when investigating acts/deeds provided for by criminal law in joint teams.

Knowledge of the legislation governing the evidentiary processes in which forensic specialists bring their contribution, and a dissociation of the procedure from the technique used, the tactics applied are necessary in order to delineate the object of forensic science from other related disciplines, such as:

- criminology, which studies the causes, factors and typologies specific to criminal phenomena, as well as the dynamics of acts provided for by the criminal law;

- forensic (judicial) psychology, which is related to forensic science in that it "interprets human behaviours with criminogenic finality" and elucidates issues which arise as concrete, specific situations due to human behaviour

\footnotetext{
${ }^{18}$ Article 175 , paragraph 6, in relation to Article 125 , cumulated 126 or 127 , as the case may be.
} 
and/or objective or subjective conditions that may influence both the method of trace-formation at the crime scene and the process of development of the statements of the main trial subjects, of the parties or of other participants in the criminal trial, as part of forensic psychology;

- transversal psychology ${ }^{19}$ with its specific fundamental themes, when studying the reactions of "the free and healthy human individual" 20 in the relationship between the person being heard and the investigator, in an attempt to explain the attitude and manifestations of the individual in his/her relations with himself/herself and with others.

The highlighting of the role of interdisciplinary research in sustainable development is important in view of achieving increased social capital. Thus, regardless of the methods of communication and the logic of the situational plan, the development of relationships for sustainable development is based on planning and programming, coordination and control, motivation, and resilience consultation.

\section{References}

Mircea, I. (2004). Criminalistică (Forensic Science). Bucharest: Ed. Lumina Lex.

Iancu E.A. \& M.L. Păcurariu (2018). 'Consideraţii referitoare la folosirea aeronavelor fără pilot în fotografia judiciară operativă/Considerations Regarding the Use of Unmanned Aerial Vehicles in Judicial Forensic Photography', in Noi provocări la adresa securităţii interne în Uniunii Europene (New Challenges related to the internal security within European Union), 7th ed. Bucharest: Research \& Science Published House.

Ionescu, F. (2008). Criminalistică (Forensic Science). Bucharest: Ed. Universitară.

Schwartz, Ghe. (2005). Limbajul individului om, liber și sănătos în spiritul psihologiei transversale (The Language of the Free and Healthy Human Individual within the Spirit of Transversal Psychology. Deva: Ed. Emia.

Schwartz, Ghe. (2008). Psihologia transversală. Partea generală (Transversal Psychology. The General Part). Arad: Ed. Universității Aurel Vlaicu.

Stancu, E. (2007). Tratat de criminalistică (Forensic Science Treatise), Bucharest: Ed. Universul Juridic.

2030 Agenda for Sustainable Development https://sustainabledevelopment.un.org/post 2015/transformingourworld

Decision no. 368 of 3 July 1998 on the establishment of the National Institute of Forensic Expertise - I.N.E.C.

Law no. 135/2010 on the Criminal Procedure Code.

Law no. 255/2013 for the implementation of Law no. 135/2010 on the Criminal Procedure Code.

Law no. 567 of 9 December 2004 on the status of auxiliary specialised personnel working in law courts and prosecutor's offices attached to them.

Law no. 156 of 5 July 2011 for the amendment and supplementing of Government Ordinance no. 75/2000 regarding the authorisation of criminal experts who may be

\footnotetext{
${ }^{19}$ Schwartz (2008).

${ }^{20}$ Schwartz (2005).
} 
recommended by the parties in order to participate in the performance of forensic expertise, as well as of Law no. 567/2004 on the status of auxiliary specialised personnel working in law courts and prosecutor's offices attached to them.

Order no. 2724/C of 18 July 2016 on the approval of the Regulation for organizing and conducting the competition for vacancies or temporary vacancies corresponding to the forensic specialisation performance positions within the National Institute of Forensic Expertise and forensic expertise laboratories.

Ordinance no. 75 of 24 August 2000 on the organisation of the activity of forensic expertise.

The National Institute of Forensics - https://www.politiaromana.ro/ro/politia-romana/ unitati-

The National Institute of Forensic Expertise - https://www.inec.ro/ centrale/institutulnational-de-criminalistica 
